\title{
WTO DECISION ON IMPLEMENTATION OF PARAGRAPH 6 OF THE DOHA DECLARATION ON THE TRIPS AGREEMENT AND PUBLIC HEALTH: A SOLUTION TO THE ACCESS TO ESSENTIAL MEDICINES PROBLEM?
}

\author{
Running title: WTO Decision on Implementation of Paragraph 6
}

\author{
DUNCAN MATTHEWS*
}

\begin{abstract}
The need for a legal solution to the compulsory licence problem was outlined in the Doha Declaration on the TRIPS Agreement and Public Health of 14 November 2001. The agreement subsequently reached by WTO Members on 30 August 2003 in response to paragraph 6 of the Doha Declaration is seen as key to improving access to essential medicines in developing countries. This article reexamines the negotiations that led to the 30 August agreement and assesses its likely impact. It then argues that compulsory licensing is one of a range of policy approaches that will ultimately assist in improving access to essential medicines in developing countries. The article suggests that a long-term achievement of the Doha-based negotiations is likely to be in refocusing attention on the potential of other measures that can operate alongside compulsory licensing provisions. It concludes that the debate about the Doha Declaration and compulsory licensing is part of a much wider problem and the solution requires a mix of policy initiatives.
\end{abstract}

Revised version 20 October 2003

\author{
Accepted for publication in the Journal of International Economic Law \\ Volume 7, Issue Number 1, March 2004
}

\footnotetext{
* Senior Lecturer and Senior Research Fellow, Intellectual Property Research Institute, Centre for Commercial Law Studies, Queen Mary, University of London, John Vane Science Building, Charterhouse Square, London EC1M 6BQ, United Kingdom. Email: d.n.matthews@qmul.ac.uk
} 


\section{WTO DECISION ON IMPLEMENTATION OF PARAGRAPH 6 OF THE DOHA DECLARATION ON THE TRIPS AGREEMENT AND PUBLIC HEALTH: A SOLUTION TO THE ACCESS TO ESSENTIAL MEDICINES PROBLEM?}

\section{Introduction}

This article assesses recent initiatives designed to address concern that the cost of gaining access to essential medicines required to combat epidemics in developing countries is prohibitively high. ${ }^{1}$ This problem is perceived as particularly acute because, although fewer than 5 per cent of medicines on the World Health Organisation (WHO) Model List of Essential Medicines are patented, ${ }^{2}$ many new drugs, particularly those designed to deal with the most pressing public health crisis of modern times, the HIV/AIDS virus, are subject to patent control. ${ }^{3}$ Many commentators fear that the problem of obtaining access to the medicines needed to deal with the HIV/AIDS pandemic in developing countries will be further hindered by the patent provisions of the World Trade Organisation (WTO) Agreement on TradeRelated Aspects of Intellectual Property Rights (the TRIPS Agreement). The concern is that, following the end of the transitional arrangements of the TRIPS Agreement in 2005, the extension of patent protection for pharmaceuticals in all but a few leastdeveloped countries will lead to unacceptably high prices for medicines in the developing world. ${ }^{4}$

This concern was affirmed in the report of the United Kingdom Commission on Intellectual Property Rights (CIPR), which suggested that if patents were absent in developing countries more patients would be able to afford treatment since there is considerable evidence that consumption of medicines is sensitive to price. ${ }^{5}$ But the paradox is that, conversely, in the absence of patent protection for pharmaceuticals in

\footnotetext{
${ }^{1}$ For example, World Health Organisation Intellectual Property Rights, Innovation and Public Health: Report by the Secretariat (Geneva: WHO, Fifty-Sixth World Health Assembly Provisional Agenda Item 14.9, A56/17, 12 May 2003).

${ }^{2}$ See also World Health Organisation WHO Medicines Strategy: Progress Report (Geneva: WHO, Executive Board $111^{\text {th }}$ Session Provisional Agenda Item 10.3, EB111/30, 13 December 2002) at 4. ${ }^{3}$ Jacques H.J.Bourgeois and Thaddeus J. Burns 'Implementing Paragraph 6 of the Doha Declaration on TRIPS and Public Health: The Waiver Solution', 5 (6) Journal of World Intellectual Property 835 (2002) at 839. E. Noehrenberg 'TRIPS, the Doha Declaration and Public Health', 6 (2) Journal of World Intellectual Property 379 (2003) at 381.

${ }^{4}$ See also Bourgeois and Burns, above n. 3, at 838; Faizel Ismail 'The Doha Declaration on TRIPS and Public Health and the Negotiations in the WTO on Paragraph 6: Why PhRMA Needs to Join the Consensus!', 6 (3) Journal of World Intellectual Property 393 (2003), at 395; Richard P. Rozek 'The Effects of Compulsory Licensing on Innovation and Access to Health Care', 3 (6) Journal of World Intellectual Property 889 (2000), at 896; Richard P. Rozek and Renee L. Rainey 'Broad-Based Compulsory Licensing of Pharmaceutical Technologies: Unsound Public Policy’ 4 (4) Journal of World Intellectual Property 463 (2001), at 471.

${ }^{5}$ Commission on Intellectual Property Rights Integrating Intellectual Property Rights and Development Policy, (London: Commission on Intellectual Property Rights, 2002), at 37. See also Department for International Development, The UK Government Response to The Report of the Commission on Intellectual Property Rights “Integrating Intellectual Property Rights and Development Policy”, (London: DFID, 2003), at 5; and criticisms of the CIPR Report by R.S. Crespi, 'IPRs Under Siege: First Impressions of the Report of the Commission on Intellectual Property Rights', 25 (6) European Intellectual Property Review 242 (2003).
} 
developing countries, the CIPR report also demonstrated that there may be insufficient incentive structures, with the result that investment in private sector pharmaceutical research and development (R\&D) for diseases that predominantly affect developing countries remains low. Less than 5 per cent of the estimated \$44 billion spent on R\&D is directed towards developing country diseases, while only 13 of the 1,393 new drugs approved between 1975 and 1999 are concerned with tropical diseases. ${ }^{6}$ The HIV/AIDS pandemic is particularly problematic in this respect since the majority of HIV vaccines are being developed for genetic profiles of subtype B, prevalent in developed countries, while most AIDS sufferers in developing countries are types $\mathrm{A}$ and $\mathrm{C}$, for which far less research is being carried out. ${ }^{7}$ Yet the overall situation remains complex with factors other than patents, such as health care provision, research and political commitment in developing countries, also constituting significant barriers to access to essential medicines in developing countries. The Attaran paper, for instance, argued that patents are not a significant barrier to the treatment of HIV/AIDS in Africa, with a variety of other factors such as poverty, tariffs and sales taxes and a lack of sufficient international financial aid to fund anti-retroviral treatment, being of greater significance. ${ }^{8}$

This article reviews attempts to find a solution to the problem identified in the Doha Declaration on the TRIPS Agreement and Public Health, namely a means of ensuring access to low-cost essential medicines in developing countries, which lack the manufacturing capacity to take advantage of the compulsory licensing provisions of the TRIPS Agreement when faced with public health crises. The article assesses progress made in the context of Doha-based negotiations, culminating in the Decision of the General Council of the WTO on 30 August 2003. It also highlights the significance of developments parallel to the WTO discussions, suggesting that a key achievement of the debate on the Doha Declaration on the TRIPS Agreement and Public Health may actually be the extent to which it has refocused attention on the severity of the problems faced by developing countries, providing the stimulus for wider initiatives designed to tackle the HIV/AIDS pandemic. The article concludes that, where real progress on addressing this public health crisis is made, it is likely to be in part the result of the 30 August agreement on a mechanism to resolve the Doha Declaration compulsory licensing problem. But of equal importance are a mix of policy approaches, incremental measures and pragmatic initiatives for which the Doha Declaration has provided an important catalyst, such as the actions of corporate donors of low-cost (or free) medicines, public-private partnership initiatives and increased contributions to the Global Fund by developed countries. Initiatives to prevent diversion of trade in low-cost medicines at a regional level, such as the European Union (EU) tiered pricing Regulation, also have great potential to assist at a pragmatic level. If a mix of policy approaches can assist and operate alongside the agreement on a solution to the compulsory licensing problem outlined in the Doha Declaration on the TRIPS Agreement and Public Health by improving access to lowcost essential medicines and ensuring that drugs remain in the markets for which they were intended, there is still great potential to achieve progress in the battle to address the public health crises that afflict much of the developing world.

\footnotetext{
${ }^{6}$ Commission on Intellectual Property Rights, above n. 5, at 32.

${ }^{7}$ Ibid., at 33.

${ }^{8}$ Amir Attaran and Lee Gillespie-White 'Do Patents for Antiretroviral Drugs Constrain Access to AIDS Treatment in Africa?’, 286 (15) Journal of the American Medical Association 1886 (2001).
} 
This article is divided into six parts. The first part sets out the legal context for the current debate on access to essential medicines in developing countries by reappraising the compulsory licensing provisions of the TRIPS Agreement. The second part explains why, through increasing public awareness garnered from high profile legal disputes, the access to medicines debate came to achieve such significance in the public consciousness. The third part reviews the significance of the Doha Declaration on the TRIPS Agreement and Public Health as a mechanism for acknowledging the severity of the problem. The fourth part reassesses negotiations designed to find a solution to the problem identified in the Doha Declaration through negotiations at WTO level, culminating in the agreement endorsed by the General Council of the WTO on 30 August 2003. The fifth part examines alternatives to a Doha-based solution and suggests that these may also be significant, while the sixth part concludes by suggesting that, although some of these policy alternatives have not received the same degree of attention as Doha-based negotiations, they also have great potential to assist in improving access to essential medicines in developing countries in the long run.

\section{Compulsory licensing, access to essential medicines and the TRIPS Agreement}

On the face of it, the TRIPS Agreement deals adequately with the issue of patents, access to essential medicines and public health crises in developing countries through Articles 7, 8 and 31. Article 7 provides that the protection and enforcement of intellectual property rights should contribute not only to the promotion of technological innovation but also to the transfer and dissemination of technology to the mutual advantage of producers and users of technological knowledge ${ }^{9}$ in a manner conducive to social and economic welfare and which balances rights and obligations. ${ }^{10}$ Further safeguards appear in Article 8(1), which provides that, when Members implement the TRIPS Agreement, they may adopt measures necessary to protect public health and nutrition and to promote the public interest in sectors of vital importance to their socio-economic and technological development, provided such measures are consistent with the provisions of the Agreement.

Article 31 refers to 'other use', that is to say use other than that permitted under Article $30 .{ }^{11}$ So, although not expressly referred to as compulsory licensing provisions, Article 31 allows for 'use without authorisation', in effect a compulsory licence granted by the competent national authority to allow that national authority or a third party to manufacture a patented product without the authorisation of the right

\footnotetext{
${ }^{9}$ In relation to least-developed countries, Article 66(2) also provides that 'Developed country Members shall provide incentives to enterprises and institutions in their territories for the purpose of promoting and encouraging technology transfer to least-developed country Members in order to enable them to create a sound and viable technological base.'

${ }^{10}$ Article 7 has generally been interpreted as the promise of foreign direct investment and technology transfer to developing countries in return for becoming signatories to the TRIPS Agreement. See, for example, Sandra Bartelt 'Compulsory Licences Pursuant to TRIPS Article 31 in the Light of the Doha Declaration on the TRIPS Agreement and Public Health', 6 (2) Journal of World Intellectual Property 283 (2003), at 286; Paul Vandoren 'Médicaments sans Frontières? Clarification of the Relationship between TRIPS and Public Health resulting from the WTO Doha Ministerial Declaration,' 5 (1) Journal of World Intellectual Property 5 (2002), at 8.

${ }^{11}$ Article 30 of the TRIPS Agreement is discussed later, in IV.D of this article.
} 
holder. ${ }^{12}$ In this respect, the public interest goal of achieving broader access to the patented invention is considered more important than the private interest of the right holder in fully exploiting his exclusive rights. ${ }^{13}$ What this means in the context of public health imperatives is that compulsory licensing is intended to permit countries to produce generic drugs that are more affordable than patented proprietary medicines. Since this amounts to an exception to the exclusive rights of the patent holder Article 31 also sets out restrictive conditions that must be satisfied before a compulsory licence can be awarded. ${ }^{14}$ These conditions include, under Article 31(b), a requirement that a reasonable period of time is allowed to negotiate a licence with the right holder on the basis of reasonable commercial terms, but this requirement of prior negotiation and adequate remuneration can be waived in the event of a national emergency or other circumstances of extreme urgency. ${ }^{15}$ So, on the face of it, compulsory licences could be granted by a developing country without prior negotiation with the holder of rights to key pharmaceutical patents in the case of a public health crisis of epidemic proportions. Safeguards on duration of the compulsory licence are set out in Article 31 (g), which provides that authorisation for such use shall be liable to be terminated if and when the circumstances which led to it cease to exist and are unlikely to recur.

However, under Article 31(f), generic drugs produced under a compulsory licence 'shall be authorized predominantly for the supply of the domestic market of the Member authorizing such use'. ${ }^{16}$ This has the practical effect of preventing

\footnotetext{
${ }^{12}$ See also Bartelt, above n. 10, at 288. For a history of compulsory (or 'non-voluntary') licensing, with particular reference to the Paris Convention of 1883 and subsequent Conferences that attempted to amend and clarify compulsory licence provisions in Article 5A of the Paris Convention, see Jerome H. Reichman with Catherine Hasenzahl 'Non-voluntary Licensing of Patented Inventions: Historical Perspective, Legal Framework under TRIPS, and an Overview of the Practice in Canada and the United States of America', (Case Study for UNCTAD/ICTSD Capacity Building Project on Intellectual Property Rights and Sustainable Development, 2002). For a negotiating history of Article 31 of the TRIPS Agreement see E. Richard Gold and Danial K. Lam 'Balancing Trade in Patents: Public NonCommercial Use and Compulsory Licensing’, 6 (1) Journal of World Intellectual Property 5 (2003).

${ }^{13}$ Reichman, above n. 12, at 4.

${ }^{14}$ Although there is disagreement as to whether Article 31 contains an exhaustive list of circumstances under which compulsory licences can be granted (for an excellent discussion of this point, see Bartelt, above n. 10, at 295 for an analysis, at fn. 64, of the narrow interpretation of Article 31 adopted by Rozek, above n. 4, at 904); and Rozek and Rainey, above n. 4, at 468). According to Bartelt, the pharmaceutical industry held the opinion that Article 31 should be read as a narrow exception, limiting the grounds for compulsory licensing to those expressly mentioned in it. This contrasts with the provisions of Paragraph 5(b) of the Doha Declaration, which states that each Member has the freedom to determine the grounds upon which a compulsory licence can be granted. Bartelt contends that this view seems supported by reading Article 31 in conjunction with Article 8, which allows Members to adopt measures necessary to protect public health and to promote the public interest in sectors of vital importance to their socio-economic development. In any case, a national emergency is specifically mentioned in Article 31(b) of the TRIPS Agreement and the status of public health crises as national emergencies was confirmed by Paragraph 5(c) of the Doha Declaration, which specifies that public health crises, including those relating to HIV/AIDS, tuberculosis, malaria and other epidemics, can represent a national emergency or other circumstances of extreme urgency.

${ }^{15}$ For a theoretical and empirical analysis of royalties set under compulsory licences see F.M. Scherer and Jayahree Watal 'Post-TRIPS Options for Access to Patented Medicines in Developing Nations', 5 JIEL 913 (2002).

${ }^{16}$ For a discussion of the meaning of 'predominantly' within the context of Article 31(f), see Frederick M. Abbott 'Compulsory Licensing for Public Health Needs: the TRIPS Agreement at the WTO after the Doha Declaration on Public Health', Quaker United Nations Office - Geneva, Occasional Paper 9 (2002), at 26.
} 
exports of generic drugs to countries that do not have significant pharmaceutical industries themselves. ${ }^{17}$ Only about a dozen developing countries, among them China, India, Brazil, Argentina and South Africa have the level of manufacturing capacity capable of producing significant quantities of off-patent generic drugs. For countries with insufficient manufacturing capacity, the only realistic sourcing mechanism is importation. Under the transitional arrangements of the TRIPS Agreement, developing countries can currently buy generic drugs from a few producers in countries such as India, but they will be unable to do so after 1 January 2005 when, under transitional arrangements set out in Article 65(4), developing countries will be required to extend product patent protection to areas of technology not protected on the general date of application of the TRIPS Agreement. ${ }^{18}$ This Article 31(f) problem will be exacerbated from 2005 by the fact that a WTO Member experiencing a public health crisis will be unable to import generic pharmaceutical products under compulsory licensing conditions from other Member unless the latter country has also invoked an equivalent compulsory licence and, in any case, since Article 31(f) specifies that manufacture must be 'predominantly' for supply of the domestic market in the manufacturing Member country rather than for export, any assistance of this kind from another country is likely to be limited. ${ }^{19}$

\section{Increasing public awareness: the access to essential medicines debate}

The potential impact of the TRIPS Agreement on access to essential medicines was brought sharply into focus in March 2001 in South Africa, ${ }^{20}$ when forty-one global pharmaceutical companies, represented by the Pharmaceutical Manufacturers Association of South Africa, objected to provisions of the South African Medicines Act, which gave the Health Minister the power to grant compulsory licences for patented pharmaceutical products when public health was at stake. ${ }^{21}$ The legal action brought, but subsequently abandoned, by the Pharmaceutical Manufacturers Association of South Africa concerned, in particular, Article 10 of the South African Medicines and Related Substances Control Amendment Act 1997, which added Section 15C to the 1965 Medicines and Related Substances Control Act, ${ }^{22}$ in doing so allowing the Health Minister to abrogate patents, issue compulsory licences and allow

\footnotetext{
${ }^{17}$ Concept Paper Relating to Paragraph 6 of the Ministerial Declaration on the TRIPS Agreement and Public Health, Communication from the EC and their Member States to the TRIPS Council, IP/C/W/339, 4 March 2002. See also Frederick F. Abbott 'The TRIPS Agreement, Access to Medicines and the WTO Doha Ministerial Conference', Quaker United Nations Office - Geneva, Occasional Paper 7 (2001), at 13; Bartelt, above n. 10, at 284, 296.

${ }^{18}$ See also Bourgeois and Burns, above n. 3, at 838.

${ }^{19}$ See also Arvind Subramanian 'The AIDS Crisis, Differential Pricing of Drugs, and the TRIPS Agreement’ 4 (3) Journal of World Intellectual Property 323 (2001), at 326.

${ }^{20}$ South Africa had already adopted measures necessary to comply with the TRIPS Agreement by virtue of the Intellectual Property Laws Amendment Act No. 38 of 1997.

${ }^{21}$ See Notice of Motion in the High Court of South Africa (Transvaal Provincial Division) Case No. 4183/98, http://www.cptech.org/ip/health/sa/pharmasuit.html (visited 3 June 2003).

${ }^{22}$ Section 15C: 'The Minister may prescribe conditions for the supply of more affordable medicines in certain circumstances so as to protect the health of the public and, in particular may: (a) notwithstanding anything to the contrary contained in the Patent Act 1978 (Act No. 57 of 1978), determine that the rights with regard to any medicine under a patent granted in the Republic shall not extend to acts in respect of such medicine...'. (Bartelt, above n. 10, at 291, fn. 49, quoting Amendment Act reprinted in Tshimanga Kongolo 'Public Interest versus the Pharmaceutical Industry's Monopoly in South Africa’, 4 (5) Journal of World Intellectual Property 605 (2001), at 605).
} 
parallel imports of pharmaceutical products in order to increase availability and lower the cost of medicines. ${ }^{23}$

In terms of the TRIPS Agreement, what the South African legislation lacked were the detailed provisions required by Article 31 of the TRIPS Agreement, particularly the requirement that compulsory licensing be granted only on a nonexclusive and non-assignable basis, with the possibility of judicial review and with adequate remuneration for the patent holder. ${ }^{24}$ But the compatibility of the South African compulsory licensing provisions with Article 31 of the TRIPS Agreement was difficult to ascertain conclusively since the exceptions in the South African Amendment Act are considered ambiguous. ${ }^{25}$ The case proved particularly emotive because access to anti-retroviral drugs for the treatment of HIV/AIDS, such as AZT (Zidovudine), was constrained in South Africa by the prohibitively high price of those medicines. The Pharmaceutical Manufacturers Association of South Africa ultimately abandoned the threat of court action in the face of intense public pressure. But by then the case had brought the access to essential medicines debate to the fore in public consciousness. South Africa, with an estimated 4.5 million citizens infected with HIV, has since become the focus of widespread concern due to its own government's unconventional treatment policies. In August 2003, South African Health Minister Manto Tshabalala-Msimang reiterated the government's refusal to implement an antiretroviral drugs programme, proposing instead that HIV/AIDS sufferers eat garlic, onions, olive oil and African potatoes to boost their immune systems.

The controversial nature of compulsory licensing provisions of the TRIPS Agreement was reinforced by WTO dispute settlement proceedings initiated by the United States ${ }^{26}$ against Brazil a few months later in June 2001. ${ }^{27}$ The US complaint was that Article 68 of the Brazilian Industrial Property Law (Law 9.279/96), which permitted the granting of a compulsory licence where there is a lack of local manufacturing of the patented product, was incompatible with the principle of nondiscrimination set out in Article 27(1) of the TRIPS Agreement. However, in the face of criticism from the international community, the United States ultimately withdrew its complaint to the WTO and notified a Mutually Agreed Solution ${ }^{28}$ on 19 July 2001, following Brazil's commitment to hold prior talks to permit constructive discussion should Brazil consider it necessary to use Article 68 of the national industrial property law to grant a compulsory licence on patents held by US companies. ${ }^{29}$

But, while an appreciation of the potential of compulsory licensing as a public policy tool in developing countries appeared to be growing following the South

\footnotetext{
${ }^{23}$ Kongolo, above n. 22, at 875; R.L. Ostergard, 'The Political Economy of the South Africa-United States Patent Dispute’, 2 (6) Journal of World Intellectual Property, 875 (1999), at 612.

${ }^{24}$ Frank Wooldridge 'Affordable Medicines - TRIPS and United States Policies', 4 (1) Intellectual Property Quarterly 103 (2000), at 108.

${ }^{25}$ Bartelt, above n. 10, at 292.

${ }^{26}$ Request for consultations by the United States, Brazil - Measures Affecting Patent Protection, WT/DS199/1, 8 June 2001.

${ }^{27}$ See also Daya Shanker, 'Brazil, the Pharmaceutical Industry and the WTO', 5 (1) Journal of World Intellectual Property 52 (2002) 53.

${ }^{28}$ Notification of Mutually Agreed Solution, Brazil - Measures Affecting Patent Protection, WT/DS/199/4, 19 July 2001.

${ }^{29}$ Vandoren, above n. 10, at 7. See also Daya Shanker, above n. 27, at 53.
} 
African and Brazilian cases, ${ }^{30}$ there were also countervailing concerns that the aggressive use of compulsory licences to address public health imperatives in developing countries may obscure the potential of more innovative policy instruments, such as encouraging foreign direct investment into local manufacturing facilities and discouraging foreign direct investment and technology transfer to developing countries. ${ }^{31}$ Rozek and Rainey, for instance, have warned against the potentially harmful effects in developing countries that adopt a broad-based compulsory licensing regime as a means by which developing countries can gain access to patented pharmaceutical products on grounds that compulsory licensing destroys the incentives for research and development on diseases specific to developing countries, that it imposes costs on national governments faced with having to approve and monitor the products produced under licence, and because compulsory licensing may encourage a culture of widespread illegal copying of patented products in developed country markets. ${ }^{32}$

But, as Rozek and Rainey themselves acknowledge, in many respects the real value of compulsory licensing can be found not in its actual use, but in the mere threat of its use - a mechanism used successfully by Brazil in negotiations with pharmaceutical companies to negotiate an affordable price for anti-retroviral drugs for the treatment of HIV/AIDS. ${ }^{33}$ This leverage role for compulsory licensing has also been observed in the US, where legislation broadly authorises the government and its contractors to make use of patented inventions without the patentee's permission and without access to injunctive relief to prevent infringement and where a number of statutes also allow private compulsory licences on specific public health grounds. ${ }^{34}$ In their negotiations with Bayer over acquisition of large quantities of Ciprofloxacin (Cipro) to address the threat posed by the anthrax virus, for example, the United States successfully negotiated a lower price for Cipro in the face of possible compulsory licences. ${ }^{35}$ Overall, what the recent experiences of Brazil and the United States demonstrate is that the mere threat of compulsory licences may often be as, if not more, effective in achieving public policy objectives than actual use. ${ }^{36}$

\section{The Doha Declaration on the TRIPS Agreement and Public Health}

WTO Members adopted the Declaration on the TRIPS Agreement and Public Health at the $4^{\text {th }}$ Ministerial Conference in Doha on 14 November 2001 in response to concerns about higher prices for patented drugs and the use of compulsory licences, particularly the requirement that they be issued in accordance with Article 31 and

\footnotetext{
${ }^{30}$ See, for example, reports that the NGO Consumer Project on Technology (CPTech) has recently been 'coaching' groups in South Africa, Ghana, Uganda and Kenya to mount legal bids for compulsory licences: 'Africa's Aids Drugs Trapped in the Laboratory. Kenya has the pills. Now the fight is on to get them to the people', Rory Carroll, The Guardian, 21 May 2003, http://www.guardian.co.uk/international/story/0,3604,960106,00.html (visited 22 May 2003).

${ }^{31}$ Reichman, above n. 12, at 26-27.

${ }^{32}$ Rozek and Rainey, above n. 4, at 464.

${ }^{33}$ See also Bartelt, above n. 10, at 307; Vandoren, above n. 10 at 9.

${ }^{34}$ Reichman, above n. 12, at 10.

${ }^{35}$ See also Frederick M. Abbott, 'The Doha Declaration on the TRIPS Agreement and Public Health: Lighting A Dark Corner’, 5 (2) JIEL 469 (2002), at 486.

${ }^{36}$ See also Reichman, above n. 12, at 13.
} 
should be predominantly for domestic use. ${ }^{37}$ The Doha Declaration, originally an initiative of the African Group of WTO Members ${ }^{38}$ and a 'concrete success' for developing countries, ${ }^{39}$ recognised the gravity of the public health problems afflicting many developing and least-developed countries especially those resulting from HIV/AIDS, tuberculosis, malaria and other epidemics. It stressed the need for the TRIPS Agreement to be part of wider national and international action to address these problems. It reaffirmed that the TRIPS Agreement does not and should not prevent measures to protect public health and that the TRIPS Agreement should be interpreted and implemented in a manner supportive of WTO Members' rights to protect public health and, in particular, to promote access to medicines for all. The Declaration recognised the flexibilities contained in the TRIPS Agreement with respect to the right to grant compulsory licences and the freedom to determine the grounds upon which such licences are granted; the right of each Member to determine what constitutes a 'national emergency' or other circumstances of extreme emergency, it being understood that public health crises can represent a national emergency or other circumstances of extreme emergency; ${ }^{40}$ and the effect of provisions of the TRIPS Agreement that allow each Member freedom to establish its own regime for exhaustion of intellectual property rights. ${ }^{41}$

But the main problem was that the compulsory licensing provisions of the TRIPS Agreement were of little practical use to countries with little or no pharmaceutical manufacturing capabilities, since developing countries could not import from other Members with manufacturing capacity until the second Member had also invoked a compulsory licence and that even then the second Member would fall foul of Article 31(f) because the compulsory licence would have to be 'predominantly for the supply of the domestic market' of the Member granting the licence. $^{42}$ In recognition of this problem, paragraph 6 of the Doha Declaration explicitly recognised that WTO Members with insufficient or no manufacturing capacities in the pharmaceutical sector could face difficulties in making effective use of compulsory licensing under the TRIPS Agreement. Paragraph 6 set a deadline of the end of 2002 by which the Council for TRIPS (hereafter the TRIPS Council) was instructed to find an expeditious solution to this problem and report to the General Council of the WTO. Overall, then, the text of the Doha Declaration was interpretive in nature and designed to reaffirm the flexibilities already contained in the provisions of Article 31 of the TRIPS Agreement. ${ }^{43}$

\footnotetext{
${ }^{37}$ The Doha Declaration on the TRIPS Agreement and Public Health, WT/MIN(01)/DEC/W/2,14 November 2001.

${ }^{38}$ According to Tshimanga Kongolo ‘TRIPS, the Doha Declaration and Public Health', 6 (2) Journal of World Intellectual Property 373 (2003), at 374.

${ }^{39}$ Peter Drahos ‘Developing Countries and International Intellectual Property Standard-Setting', 5 (5) Journal of World Intellectual Property 765 (2002) at 781.

${ }^{40}$ This rectifies the misguided notion that Members must proclaim a fully-fledged national emergency in order to grant compulsory licences for patented pharmaceutical products under Article 31 (Reichman, above n. 12, at 15).

${ }^{41}$ According to the doctrine of international exhaustion, patented pharmaceutical products placed on the market at low prices in developing countries can be re-sold and exported to other countries under the doctrine of international exhaustion (see also Reichman, above n. 12, at 15).

${ }^{42}$ Bartelt, above n. 10, at 296.

${ }^{43}$ Noehrenberg, above n. 3, at 379. See also Alan O. Sykes 'TRIPS, Pharmaceuticals, Developing Countries, and the Doha "Solution”, John M. Olin Law and Economics Working Paper No. 140 (2002), at 9 .
} 
What of the legal status of the Declaration? When disputes arise over measures taken by Members on public health grounds, Vandoren claims that the Declaration can be used to argue that the panel should interpret the TRIPS Agreement in a manner supportive of a Member's right to protect public health. ${ }^{44}$ Bartelt also suggests that, by virtue of Article 31(3) of the Vienna Convention, the Doha Declaration should be regarded as 'subsequent practice in application of the treaty' because paragraph 5(a) of the Declaration gives clear guidelines for interpretation, stating that the TRIPS Agreement shall be read in the light of the object and purpose of the Agreement as expressed, in particular its objectives and principles. ${ }^{45}$ However, Reichman offers a word of caution, acknowledging that Article 31(3) of the Vienna Convention may apply, but also stressing that the precise legal status of the Doha Declaration does remain uncertain, the practical implication being uncertainty as to the extent to which future WTO panels and the Appellate Body will draw guidance from the Declaration when deciding upon complaints. ${ }^{46}$

\section{Negotiations on possible solutions}

In an attempt to resolve the issues identified in paragraph 6 of the Doha Declaration, negotiations between WTO Members, meeting within the TRIPS Council, took place throughout 2002 and 2003, culminating in the agreement endorsed by the General Council of the WTO on 30 August 2003. When the TRIPS Council met in June 2002, five Communications had been submitted by WTO Members proposing paragraph 6 solutions, ${ }^{47}$ with two further communications from the WTO Secretariat, providing available information on the existence of patents in regard to diseases referred to in the Doha Declaration and on the manufacturing capacity of medicines. ${ }^{48}$ As with the earlier negotiations on the text of the TRIPS Agreement, the US and European Union were extremely active in support of their pharmaceutical industries. ${ }^{49}$ However, unlike the original TRIPS negotiations, the process prompted by paragraph 6 of the Doha Declaration was also marked by a far greater degree of involvement on the part of developing countries, supported by Non-Governmental Organisations (NGOs). ${ }^{50}$

\footnotetext{
${ }^{44}$ Vandoren, above n. 10, at 8.

${ }^{45}$ Bartelt, above n. 10, at 302.

${ }^{46}$ Reichman, above n. 12 , at 14.

${ }^{47}$ Communication from the European Communities and their Member States, above n 17; Proposal on Paragraph 6 of the Ministerial Declaration on the TRIPS Agreement and Public Health, Joint Communication from the African Group of the WTO, IP/C/W/351, 24 June 2002; Paragraph 6 of the Ministerial Declaration on the TRIPS Agreement and Public Health, Communication from the United Arab Emirates, IP/C/W/354, 24 June 2002; Paragraph 6 of the Ministerial Declaration on the TRIPS Agreement and Public Health, Communication received from the Permanent Mission of Brazil on behalf of the delegations of Bolivia, Brazil, Cuba, China , the Dominican Republic, Ecuador, India, Indonesia, Pakistan, Peru, Sri Lanka, Thailand, and Venezuela, IP/C/W/355, 24 June 2002; Paragraph 6 of the Ministerial Declaration on the TRIPS Agreement and Public Health, Second Communication from the United States, IP/C/W/358, 9 July 2002.

${ }^{48}$ Available Information on the Existence of Patents in Regard to Diseases Referred to in the Declaration on the TRIPS Agreement and Public Health, Note by the Secretariat, WTO, Geneva, IP/C/W/348, 11 June 2002; Available Information on Manufacturing Capacity for Medicines, Note by the Secretariat, WTO, Geneva, IP/C/W/345, 24 May 2002.

${ }^{49}$ For a comparison of US and EU TRIPS negotiating strategies, see Duncan Matthews, 'Globalising Intellectual Property Rights: The TRIPS Agreement’, (London: Routledge, 2002) 29-45.

${ }^{50}$ Susan K. Sell, 'TRIPS and the Access to Medicines Campaign', paper prepared for 'Access to Medicines for the Developing World: International Facilitation or Hindrance?' Conference sponsored by the University of Wisconsin Law School, Madison, Wisconsin, 9-10 March 2002, at 15, has identified the higher profile role of NGOs from civil society in the post-TRIPS debate as being largely
} 


\section{A. Dispute settlement moratorium}

As for the negotiations, in June 2002 the African Group proposed a moratorium on bringing complaints against low-income developing countries before the Dispute Settlement Body of the WTO in relation to Article 31(f) of the TRIPS Agreement. ${ }^{51} \mathrm{~A}$ month later the United States also put forward proposals for a moratorium, ${ }^{52}$ an offer later acted upon by the US in December 2002 as a measure to provide developing countries with temporary relief from dispute settlement actions following failure to meet the paragraph 6 deadline of the Doha Declaration. ${ }^{53}$ The advantage of a moratorium was that it would set aside any WTO dispute settlement proceedings that might otherwise arise for breach of Article 31(f) of the TRIPS Agreement through the production and export of pharmaceutical products to a third country in order to address a public health crisis in the latter. ${ }^{54}$ However, since there was arguably no sound legal basis for not applying the dispute settlement procedure in instances of a moratorium $^{55}$ there was a risk that, even as a temporary arrangement, a moratorium on disputes against Members that take action to address public health crises in countries with insufficient or no manufacturing capacities was likely to have the inherent problem of lacking legal certainty as to the behaviour of potential complainants, particularly developed country WTO Members. ${ }^{56}$

There was also the problem that implicit in the moratorium is the proviso that it would apply only if developing countries compensate patent holders for compulsory licences, and only until the expected end date of the Doha Development Round of multilateral trade negotiations in January 2005, when the transitional arrangements for developing countries under Article 65(4) of the TRIPS Agreement will also come to an end. With the prospect of a temporary solution of the kind offered by a moratorium lasting only until the end of the Doha Round, the likelihood was that trade-offs and package deals would emerge, as they did during the original TRIPS negotiations, with developing countries offered trade advantages and market access in key areas, such as

attributable to the work of the organisations such as Consumer Project on Technology (CPTech), a USbased NGO focusing on information technologies, intellectual property and research and development, and Health Action International (HAI) a global network of health, development, consumer and other public interest groups, based in the Netherlands. CPTech and HAI have been active in the debate surrounding patents, access to medicines and public health since the mid-1990s. Meanwhile, Peter Drahos, above n. 39, has identified NGOs as having had a crucial role in the rise of influence of the Africa Group, both in relation to public health and biodiversity issues. In particular, the Quaker UN Office has also played a key role in the public health debate through the work of its consultant Geoff Tansey and the influential report it commissioned from Frederick Abbott, above n. 17, in the run-up to the Doha Ministerial Meeting, which itself reflected the comments of James Love and Ellen 'T Hoen of NGOs CPTech and MSF respectively, together with academics Carlos Correa and Jerome Reichman. Oxfam has also been active through the work of Ruth Mayne and briefing papers such as 'TRIPS and Public Health: the next battle', http://www.oxfam.org.uk/policy/papers/15trips/15trips.html (visited 25 April 2003).

${ }^{51}$ Proposal on Paragraph 6 of the Ministerial Declaration on the TRIPS Agreement and Public Health, Joint Communication from the African Group in the WTO, IP/C/W/351, 24 June 2002, para. 6(g).

${ }^{52}$ Second Communication from the United States, above n. 47.

${ }^{53}$ US Announces Interim Plan to Help Poor Countries Fight HIV/AIDS and Other Health Crises in Absence of WTO Consensus', USTR Press Release: http://www.ustr.gov.releases/2002/12/02-119.htm (visited 21 December 2002).

${ }^{54}$ Kongolo, above n. 22, at 377.

${ }^{55}$ Bourgeois and Burns, above n. 3, at 851.

${ }^{56}$ See also Bourgeois and Burns, above n. 3, at 852; Ismail, above n. 4, at 400. 
agriculture, in return for agreeing to the more restrictive interpretation of Article 31(f) proposed by developed countries.

\section{B. Waiver of Article 31(f) pursuant to Article IX.3 of the WTO Agreement}

As an alternative to the moratorium approach, the United States suggested ${ }^{57}$ that WTO Members facing a public health crisis but lacking domestic manufacturing capacity could be granted a waiver of Article 31(f) to allow manufacture and export under a compulsory licence within the territory of another Member, at least until a definitive solution to paragraph 6 of the Doha Declaration has been put in place. ${ }^{58} \mathrm{~A}$ waiver could be achieved by means of Article IX.3-4 of the WTO Agreement, under the terms of which the Ministerial Conference can waive an obligation imposed on a Member by the TRIPS Agreement in 'exceptional circumstances'. It was envisaged that the waiver would not be limited by duration, provided it is reviewed on an annual basis by consensus or a three-fourths vote, following a request for a waiver, made to the TRIPS Council by the Member concerned. ${ }^{59}$ The request for a waiver from a developing country would initially be submitted to the TRIPS Council, following which the Ministerial Conference may approve the waiver by consensus or a three quarters vote. Since a waiver would be temporary, it would have the advantage over a permanent amendment of the TRIPS Agreement that it would not require the approval of parliamentary bodies within WTO Members and could be tailored to the specific objectives of the public health crisis in question. ${ }^{60}$

C. Amendment to Article 31(f) of the TRIPS Agreement to allow exports of products produced under compulsory licence

Procedurally, an amendment to the TRIPS Agreement to deal with the crux of the compulsory licensing problem, (namely the requirement under Article 31(f) that compulsory licences be 'predominantly for the supply of the domestic market of the Member authorising such use'), could be achieved, in accordance with Article X.1 of the WTO Agreement, by a consensus or a two-thirds majority of the Ministerial Conference. As proposed by the Communication from the European Communities (EC) and their Member States of 4 March 2002, ${ }^{61}$ such an amendment could, for example, state that in exceptional circumstances, Article 31(f) would not apply to compulsory licences granted by a Member for the purpose of supplying another Member with a product necessary to address a public health crisis, provided that measures were put in place to avoid abuses, re-exportation and trade diversion. ${ }^{62}$

\footnotetext{
${ }^{57}$ Second Communication from the United States, above n. 47.

${ }^{58}$ See also Abbott, above n. 17, at 32; Bourgeois and Burns, above n. 3, at 853; Bartelt, above n. 10, at 298; Thomas A. Haag 'TRIPS Since Doha: How Far Will the WTO Go Toward Modifying the Terms of Compulsory Licensing?’, 84 (12) Journal of the Patent and Trademark Office Society 945 (2002), at 969; Kongolo, above n. 22, at 377

${ }^{59}$ Articles IX.3 and IX: 4 of the WTO Agreement. See also Bourgeois and Burns, above n 5, at 856.

${ }^{60}$ See also Abbott, above n. 16, at 20.

${ }^{61}$ Communication from the European Communities and their Member States, above n. 17, paras 18-19.

${ }^{62}$ See also Bourgeois and Burns, above n. 3, at 846; Bartelt, above n. 10, at 299; Haag, above n. 58, at 970.
} 
On 6 November 2002 the EC and their Member States, in compromise proposals ahead of the Sydney WTO Mini-Ministerial Meeting on 14-15 November 2002, reiterated the main elements of their Communication of 4 March 2002 by again advocating an amendment to Article 31(f) to allow exports of products produced under compulsory licence. By way of safeguarding against abuse, the EC's 6 November document also proposed that any solution allowing an exemption to the Article 31(f) requirement that generic drugs produced under a compulsory licence to be 'predominantly' for domestic use should be limited to the production of medicines where the gravity of public health problems afflict developing and least-developed countries, especially those resulting from HIV/AIDS, tuberculosis, malaria and other epidemics. Product coverage would include patented pharmaceuticals and diagnostic test kits needed to address public health problems.

But the US adopted a more restrictive approach. In late 2002, Assistant United States Trade Representative (USTR) for Africa, Rosa Whitaker, wrote to all African countries, urging them to support the US position. ${ }^{63}$ The Whitaker letter insisted that an exemption be limited to HIV/AIDS, tuberculosis and malaria with no scope for 'other epidemics' to be included. The US view was that broadening the exemption to cover any 'other epidemics', in keeping with the wording of the Doha Declaration, would risk the inclusion of 'lifestyle' illnesses such as obesity or the common cold that should not be excluded from the compulsory licensing provisions of the TRIPS Agreement. NGOs criticised the US approach on grounds that half of the victims of non-communicable diseases (cardiovascular diseases, cancer, diabetes, chronic respiratory diseases etc.) were from the developing world, where access to expensive patented pharmaceutical products remained limited. The Whitaker letter also argued against allowing the full range of health care products (including diagnostic kits as well as actual medicines themselves) to fall within a paragraph 6 solution, as the EC suggested, on grounds that this would divert attention from access to medicines.

\section{Differentiating between developing countries}

In a move that proposed the introduction of a new distinction between different types of developing country, previously undifferentiated in the TRIPS Agreement, the EC and US both took the view that countries benefiting from the exception should be limited to least-developed countries and nations classified by the World Bank as lowincome developing countries. ${ }^{64}$ High-income developing countries would be able to benefit from the exemption only if the low-cost medicines were needed to address situations of 'national emergency or extreme urgency' ${ }^{65}$ Eligible countries would also have to show that they have no, or insufficient, manufacturing capacity in the drugs sector (i.e. no plants manufacturing active ingredients) and that they would not be able to create such capacities in the short term. NGOs criticised the proposal to

\footnotetext{
${ }^{63}$ See The Washington Post, 'Drugs for the Poor’, 14 November 2002, A32.

${ }^{64}$ Article 65 (2)-(5), TRIPS Agreement.

${ }^{65}$ According to the World Bank classification of high-income countries among non-OECD economies are: Brunei, French Polynesia, Guam, Hong Kong China, Macao China, New Caledonia, N. Mariana Islands, Singapore and Taiwan, Slovenia, Andorra, Channel Islands, Cyprus, Faroe Islands, Greenland, Liechtenstein, Monaco, Israel, Kuwait, Qatar, United Arab Emirates, Aruba, Bahamas, Bermuda, Cayman Islands, Netherlands Antilles, and Virgin Islands.
} 
restrict the exemption to low-income economies on grounds that this condition denied equal rights of access to generic medicines for at least 72 developing countries that could not, with the probable exception of China, produce these generic versions of the new drugs for themselves, nor do so at a reasonable price.

EC and US proposals that would have prevented high-income developing countries from benefiting from the new rules were also criticised by developing countries, including Brazil, India, South Africa, Kenya, Thailand, China and Egypt. These countries argued that proposals by the developed nations amounted to an attempt to differentiate among the potential beneficiary countries to an extent not agreed upon by paragraph 6 of the Doha Declaration, which simply refers to countries with 'insufficient or no manufacturing capacities'. The developing countries argued that all WTO Members should be allowed to judge for themselves whether they meet these criteria.

\section{Exporting countries}

Another major sticking point arose over which countries should be allowed to qualify as exporters of low-cost essential medicines. While the EC proposed that all WTO Members should qualify, the Whitaker letter confirmed the US position that exporter status under the exemption should be limited to least-developed and developing countries as a means of encouraging investment in their domestic pharmaceutical industries. ${ }^{66}$ Permitting developed countries to be exporters would, in the opinion of the US, simply hinder technology transfer and pharmaceutical company investment in the developing world.

This US proposal was criticised by NGOs as having the effect of reducing the number of potential suppliers of generic medicines that would be able to produce lowcost medicines. The main problem with this solution was that the company supplying cheap generic drugs would have to ask the government of its own country to override the relevant patent before any export could take place. ${ }^{67}$ This would make the importing country dependent on the political will of another government and potentially increase the administrative cost burden.

The African Group signalled flexibility on possible safeguards imposed on the country making the generic drug. They proposed that safeguards could include a requirement to export all of the production to the country issuing the licence and to require special labelling of the drug. But they argued that proposals to require special colouring and shaping of pills might increase production costs and should be avoided.

\footnotetext{
${ }^{66}$ See also Second Communication from the United States, above n. 47, para 15.

${ }^{67}$ Abbott has suggested overcoming the problems created by Article 31(f) by creating 'streamlined parallel compulsory licensing arrangements' (Abbott, above n. 16, at 28) under which a country of export might choose to recognise the grant of a compulsory licence issued by an importing country by issuing a parallel grant of a compulsory licence in the country of export, but this has the drawback that the exporting country faces the limitation imposed by Article 31(f) requiring compulsory licences to be predominantly for the supply of the domestic market authorising such use.
} 


\section{Interpretation of the 'limited exceptions' clause of Article 30}

One provision of the TRIPs Agreement that potentially offered an opportunity to make generic drugs readily available in developing countries was Article $30 .{ }^{68}$ Under Article 30, 'Members may provide limited exceptions to the exclusive rights conferred by a patent, provided that such exceptions do not unreasonably conflict with a normal exploitation of the patent and do not unreasonably prejudice the legitimate interests of the patent owner, taking account of the legitimate interests of third parties.' The Article 30 mechanism could therefore be used to authorise the making and export of patented public health related products to developing countries, where this is undertaken to fulfil unmet public health needs in countries of import. ${ }^{69}$

Although the United States consistently argued for a strict interpretation of Article $30,^{70}$ it was suggested by other WTO Members that a broader interpretation would allow Article 30 to introduce a specific exception for the purposes of supplying another Member that had granted a compulsory licence for a specific pharmaceutical product. ${ }^{71}$ In its Communication of 4 March 2002, the EC and its Member States proposed that 'WTO Members could adopt a declaration stating that a WTO Member may, in accordance with Article 30 of the TRIPS Agreement, provide that the manufacture, on its territory, of a patented product, without authorisation of the right holder, is lawful when it is meant to supply another country which has granted a licence for the import and sale of the product concerned in its territory in order to deal with a serious public health problem'. ${ }^{72}$ This view was supported by Brazil, making a submission to the TRIPS Council on behalf of a group of developing countries which, in June 2002, argued that Article 30 should be interpreted to recognise the right of WTO Members to authorise third parties to address the public health needs in another country, without the consent of the patent holder. ${ }^{73}$ By this time, however, the EC and its Member States had cooled on an Article 30 solution, ${ }^{74}$ questioning its legal merits due to doubts about whether the criteria of Article 30 offer sufficient scope for an authoritative interpretation. ${ }^{75}$ The EC's shift was reportedly criticised by NGOs. ${ }^{76}$

\footnotetext{
${ }^{68}$ Particularly in the light of paragraph 4 of the Doha Declaration, which provides that: 'We agree that the TRIPS Agreement does not and should not prevent members from taking measures to protect public health. Accordingly, while reiterating our commitment to the TRIPS Agreement, we affirm that the Agreement can and should be interpreted and implemented in a manner supportive of WTO members' right to protect public health and, in particular, to promote access to medicines for all.'

${ }^{69}$ See also Abbott, above n. 16, at 6; Abbott, above n. 17, at 33.

${ }^{70}$ See, for example, Second Communication from the United States, above n. 47. See also see also Haag, above n. 58, at 960.

${ }^{71}$ See also Bartelt, above n. 10, at 299; Daya Shanker, Access to Medicines, Article 30 of TRIPS in the Doha Declaration and an Anthropological Critique of International Treaty Negotiations, 2003, mimeo, at 28.

${ }^{72}$ Communication from the European Communities and their Member States, above n. 17, para 24.

${ }^{73}$ Paragraph 6 of the Ministerial Declaration on the TRIPS Agreement and Public Health, Communication received from the Permanent Mission of Brazil on behalf of Bolivia, Brazil, Cuba, China, the Dominican Republic, Ecuador, India, Indonesia, Pakistan, Peru, Sri Lanka, Thailand and Venezuela, IP/C/W/355, 24 June 2002.

${ }^{74}$ Communication from the EC and their Member States to the TRIPS Council Relating to Paragraph 6 of the Doha Declaration on the TRIPS Agreement and Public Health, IP/C/W/352, 20 June 2002.

${ }^{75}$ Haag, above n. 58, at 957.

${ }^{76}$ According to Bourgeois and Burns, above n. 3, at 842.
} 
Despite the cooling of enthusiasm on the part of the EC and their Member States, on 23 October 2002 an EU institution, the European Parliament (EP) adopted, (during the first reading of the draft Directive to update Directive 2001/83/EC relating to medicinal products for human use), proposals for an Article 30 solution in the form of Amendment 196. ${ }^{77}$ Amendment 196 stated that: 'Manufacturing shall be allowed if the medicinal product is intended for export to a third country that has issued a compulsory licence for that product, or where a patent is not in force and if there is a request to that effect of the competent public health authorities of that third country.' Amendment 196, which was consistent with contemporaneous proposals by the $\mathrm{WHO}^{78}$ set out a basic framework for a solution to the paragraph 6 problem by allowing generic manufacturers in any country to supply consumers in any country, so long as the sale of that product was legal and appropriate in the country where it was used by patients, and so long as the legitimate rights, if any, of the patent owners, were protected in the country where the product was consumed. Doubts have already been raised, however, about the extent to which circumstances can amount to a 'limited exception' within the meaning of Article 30 following the WTO Dispute Settlement Panel Decision on Sections 55.2(1) and (2) of the Canadian Patent Act. ${ }^{79}$

For Haag, ${ }^{80}$ neither the narrower permissive interpretation of Article 30 proposed by the EC nor the broader authoritative interpretation advanced by developing countries are tenable solutions as they are inconsistent with the statutory construction of the TRIPS Agreement, its legislative history and an interpretation of Article 30 provided by the Dispute Settlement Body in the Canada - Patent Protection. ${ }^{81}$

The Panel Report in Canada - Patent Protection provided some guidance for the application of Article 30, indicating that a compulsory licence issued under Article 30 must meet three cumulative conditions, which must all be satisfied for the exception to fall within the scope of Article 30. First, the exception must be of a limited nature; ${ }^{82}$ second, it may not unreasonably conflict with a normal exploitation of the patent; and, third, it may not unreasonably prejudice the legitimate interests of the patent holder, taking into account the legitimate interests of third parties. ${ }^{83}$

\footnotetext{
${ }^{77}$ http://www3.europarl.eu.int/omk/omnsapir.so/calendar?APP=PDF\&TYPE=PV2\&FILE=p0021023E N.pdf\&LANGUE=EN (visited 7 November 2002).

78 In its statement to the TRIPS Council on 20 September 2002, the WHO argued that 'Among the solutions being proposed, the limited exception under Article 30 is the most consistent with this public health principle. This solution will give WTO Members expeditious authorisation, as requested by the Doha Declaration, to permit third parties to make, sell and export medicines and other health technologies to address public health needs'. See also 'Implications of the Doha Declaration on the TRIPS Agreement and Public Health’, WHO/EDM/PAR/2002.3.

${ }^{79}$ WTO Panel Report, Canada - Patent Protection of Pharmaceutical Products (Canada - Patent Protection), WT/DS114/R, adopted 17 March 2000. See also Abbott, above n. 16, at 43; Skyes, above n. 43 , at 6 .

${ }^{80}$ Haag, above n. 58, at 947.

${ }^{81}$ Panel Report, Canada - Patent Protection, above n. 79,

${ }^{82}$ For criticism of the Panel's failure to consider properly the meaning of the word 'limited' see Robert Howse, 'The Canadian Generic Medicines Panel: A Dangerous Precedent in Dangerous Times', 3 (4) Journal of World Intellectual Property 493 (2000), at 498.

${ }^{83}$ Panel Report, Canada - Patent Protection, above n. 79, para 7.20. See also Bartelt, above n. 10 at 300; Haag, above n. 58, at 962; Howse, above n. 82, at 499; Dara Williams, 'Developing TRIPS Jurisprudence: The First Six Years and Beyond, 4 (2) Journal of World Intellectual Property 177 (2001), at 186.
} 
In Canada - Patent Protection the Panel, making general reference to the goals and limitations set out in Articles 7 and 8(1) of the TRIPS Agreement and the negotiating history of the TRIPS Agreement, ${ }^{84}$ adopted a strict textual approach to the meaning of Article $30,{ }^{85}$ stressing the limited nature of the exception. ${ }^{86}$ In particular, the Panel pointed out that the language of Article 30 mirrors the language of Article 13 of the TRIPS Agreement, which in turn derives its wording from Article 9(2) of the Berne Convention and provides an exception to copyrights for fair-use. ${ }^{87}$ The implication was that, although dealing with a different category of intellectual property rights, Article 30 offers similar exceptions for the granting of compulsory licensing on health grounds. ${ }^{88}$ Section 55.2(2) of the Canadian Patent Act, authorising the manufacture and storage of patented pharmaceuticals by a third party without authorisation of the patentee with the intention of placing the patented products on the market upon expiration of the relevant patent (the 'stockpiling' provision), therefore did not constitute a 'limited exception' to patent rights under Article $30 .^{89}$

Following the Panel decision in Canada - Patent Protection, there are doubts as to whether a compulsory licence to manufacture and supply generic drugs to another WTO Member could be justified under Article 30 since it would be unlikely to meet the requirement of not conflicting with the normal exploitation of the patent, since compulsory licensing could be described as being 'diametrically opposed to the subject-matter of the patent, which is to reward the inventor for his creative efforts'. 90 However Bartelt suggests that the circumstances might be rather different were Article 30 interpreted in the light of Articles 7 and 8(1), and points out that the Canada Panel has been criticised for not mentioning explicitly these provisions. ${ }^{91}$

Procedurally, a declaration on the interpretation of Article 30 could be issued by the General Council under the provisions of Article IX.2 of the WTO Agreement. Article IX.2 provides that, after a recommendation by the Council, the decision to adopt an interpretation shall be taken by a three-fourths majority of the Members. ${ }^{92}$ The principle advantage of this declaration on the interpretation of Article 30 over an amendment of Article 31(f) is that it would not require time-consuming further ratification by national parliaments. However, this would still leave the problem that Article 28 of the TRIPS Agreement clearly states that a patent shall confer on its owner the right 'to prevent third parties not having the owner's consent from the acts of: making, using, offering for sale, selling, or importing' the patented product and

\footnotetext{
${ }^{84}$ Panel Report, Canada - Patent Protection, above n. 79, para. 7.29.

${ }^{85}$ Howse, above n. 82, at 496, is critical of the Panel's 'resort to the negotiating history of the TRIPS Agreement a source of treaty interpretation which, according to Article 32 of the Vienna Convention, may only be used in the case of the application of the interpretive sources that are obligatory under Article 31, including the purpose, object and context of the treaty, results in ambiguity or absurdity'. ${ }^{86}$ Panel Report, Canada - Patent Protection, above n. 79, para. 7.31.

${ }^{87}$ Panel Report, Canada - Patent Protection, above n. 79,para. 7.71.

${ }^{88}$ See also Haag, above n. 58, at 961; Howse, above n. 82, at 502; Williams, above n. 83, at 187.

${ }^{89}$ The Panel's lack of explicit reference to Articles 7 and 8 in its reasoning has been criticised by commentators on the outcome of this dispute (see Williams, above n. 83, at 191 and 208).

${ }^{90}$ Bartelt, above n. 10, at 300; see also Haag, above n. 58, at 965.

${ }^{91}$ Bartelt, above n. 10, at 300, see also Williams, above n. 83, at 191.

${ }^{92}$ See also Communication from the European Communities and their Member States, above n. 17, para 30; Bourgeois and Burns, above n. 3, at 842; Bartelt, above n. 10, at 301.
} 
that the mere fact that the importing country met the conditions to grant a compulsory licence does not justify the breach of the patent holder's rights in a third country. ${ }^{93}$

Overall, what these proposals to address the Article 31(f) 'problem' were seeking to achieve was 'overcoming traditional concepts of compulsory licences which focused mainly on the domestic market in accordance with the principle of territoriality, ${ }^{94}$

\section{E. Chairman's draft}

By the closing months of 2002, debate had become stymied by disagreement over the issue of which illnesses and medicines should be covered by an exception, which countries should be allowed to benefit from the exception, which countries should be allowed to produce generic equivalents of patented medicines for export, and whether the TRIPS Agreement should be formally amended.

Ambassador Eduardo Perez Motta, Chairman of the TRIPS Council, attempted to achieve progress with a compromise text on 16 December 2002, under which the TRIPS Agreement would be amended so that any country with manufacturing capacities could export, while developing countries without manufacturing capacities in the pharmaceutical sector would be allowed to benefit from this system in the face of public health problems. ${ }^{95}$ Countries with sufficient capacity and/or financial means would not be able to use the exemption system, since this would only divert resources away from those countries that need it most. Developed and high-income developing countries would opt out from the system entirely, while the disease scope would reflect the wording of the Doha Declaration.

Under the Chairman's draft, countries importing generic pharmaceutical products and using the paragraph 6 mechanism would be expected to take measures to prevent re-exportation, provided such measures were 'reasonable', 'within their means' and 'proportionate' to their administrative capacities and the risk of trade diversion. Exporting countries would be obliged to require the beneficiary company of the compulsory licence (1) to export their entire production to the countries needed and (2) to clearly identify the products through labelling or marking and through special colouring or shaping of the products themselves.

At the informal TRIPS Council meeting on 17 December 2002, Ambassador Motta made it clear that the US had little option but to accept or reject the compromise text contained in the Chairman's draft. ${ }^{96}$ Developing countries, including India, Brazil and Kenya signalled a willingness to accept the Chairman's draft, much to the dismay of some NGOs, provided there was no move to further limit the scope

\footnotetext{
${ }^{93}$ Harvey E. Bale, 'The Conflicts Between Parallel Trade and Product Access and Innovation: The Case of Pharmaceuticals', 1 JIEL 637 (1998).

${ }^{94}$ Bartelt, above n. 10, at 307.

95 'Main Elements of the Chair's 16 December 2002 Draft Compromise Decision (Perez Motta Text)', European Commission (Trade and Development) Press Release, 9 January 2003, http://europa.eu.int/comm/trade/csc/memo090103_en.htm (visited 14 January 2003).

96 'US Faces Touch Choice', BNA WTO Reporter, 18 December 2002: http://pubs.bna.com/ip/BNA/wto.nsf/is/A0A6G2B6C2 (visited at 18 December 2002).
} 
of diseases. ${ }^{97}$ But when the TRIPS Council met formally on 20 December 2002, the effective deadline for the conclusion of paragraph 6 negotiations, there was deadlock. The US blocked an agreement on grounds that the scope of coverage in the Chairman's draft was too broad and went beyond the focus of HIV/AIDS, tuberculosis and malaria. ${ }^{98}$ The US felt that the compromise text could be interpreted as meaning that drug patents could be ignored on treatments for a wide range of diseases. $^{99}$ Negotiations were suspended and Ambassador Motta asked WTO Members to resume negotiations and report to the next meeting of the TRIPS Council, which took place on 10 February 2003.

\section{F. EC compromise text}

In the interim, on 9 January 2003, the EC launched a new initiative to break the deadlock. ${ }^{100}$ The EC proposal was to remove WTO constraints requiring compulsory licences to be 'predominantly' for domestic supply in the case of medicines to combat a limited list of 22 infectious diseases (including HIV/AIDS, tuberculosis and malaria) that are generally recognised by health experts to have the most damaging impact on developing countries. Mèdecines Sans Frontières ${ }^{101}$ criticised this proposal on grounds that virtually all major African diseases for which there are patented medicines have been excluded from the list, with almost all the list's diseases comprising those for which there is no drug treatment, or where existing treatments are already off patent. But the EC proposal did contain the safeguard that, for any health concern not explicitly covered by the initial list, WTO Members wishing to import medicines under compulsory licence terms would be encouraged to seek WHO advice before doing so. ${ }^{102}$ Involving the WHO, with its public health expertise, was seen as a way of ensuring that the Doha Declaration could be used in good faith.

The TRIPS Council on 10 February 2003 failed to take the issue much further, the meeting lasting only two hours and ending in deadlock with no party willing to relinquish its key demands. At the next TRIPS Council meeting on 4-5 June 2003, attempts were made to break the deadlock in the form of Communications submitted by the European Communities and their Member States and by the African, Caribbean and Pacific (ACP) states. The EC Communication stressed that full advantage should be taken of the available expertise on health matters, particularly from the World Health Organisation (WHO), in relation to implementing the Doha Declaration, and made clear that the principles of the Doha Declaration should be carried through to issues other than compulsory licensing or parallel imports, such as 'exceptions to

\footnotetext{
97 'US Sticks to Hard Line on TRIPS, as Supachai Tries to Broker Deal', Inside US Trade, 20 December 2002.

${ }^{98}$ According to Ismail, above n. 4, at 398 the US Delegation could not obtain the mandate it needed from PhRMA to agree to the proposed solution.

99 'Consensus on TRIPS Unravels as US Blocks Deal on Scope of Diseases' Inside US Trade, 3 January 2002; see also ‘US Wrecks Cheap Drugs Deal: Cheney’s Intervention Blocks Pact to Help Poor Countries After Pharmaceutical Firms Lobby White House’, The Guardian, 21 December 2002: http://www.guardian.co.uk/international/story/0,3604,864071,00.html (visited 21 December 2002).

100 'EU Seeks to Break the Current Deadlock on WTO Access to Medicines: a multilateral solution is needed', European Commission (Trade and Development) Press Release, 9 January 2003, http://europa.eu.int/comm/trade/csc/pr090103_en.htm (visited 14 January 2003).

${ }^{101}$ Médecins Sans Frontières 'Reneging on Doha', An MSF analysis of recent attempts to restrict developing counties’ use of compulsory licensing to a set list of diseases, (2003) mimeo.

102 The idea of a WHO-certified public health crisis had earlier been suggested by Arvind Subramanian of the International Monetary Fund, above n. 19, at 328.
} 
exclusive rights or other policy options'. ${ }^{103}$ This latter statement left open the possibility of future EC support for an Article 30 based solution to the paragraph 6 problem in the future. The ACP Communication expressed disappointment at the failure to reach agreement on the 16 December 2002 Motta text and highlighted the need for technical assistance, in particular from the World Intellectual Property Organisation (WIPO), the WTO and the WHO. ${ }^{104}$ The June TRIPS Council meeting ended without any substantial progress on a solution. However, following the June meeting, reports began to appear that the United States was prepared to abandon its earlier insistence that a paragraph 6 solution cover only specific diseases (namely HIV/AIDS, tuberculosis and malaria), shifting its focus from disease coverage to limitations on eligibility aimed at low-income developing countries and leastdeveloped nations, together with safeguards against the risk of commercial export of low-cost medicines into other markets. ${ }^{105}$ This shift in the position of the United States was crucial in securing agreement on a Decision of the WTO General Council, designed to resolve the issue, at the end of August 2003.

G. The August 2003 Decision on implementation of paragraph 6 of the Doha Declaration on the TRIPS Agreement and Public Health

The final breakthrough was achieved when Ambassador Motta's successor as Chairman of the TRIPS Council, Vanu Gopala Menon of Singapore, met with a small group of WTO Members to negotiate a solution to paragraph 6. This group, comprising the United States, Kenya, Brazil, South Africa and India, succeeded in producing a draft Decision on 21 August 2003, followed by a revised draft, almost identical to the original version, on 26 August. Following approval by the TRIPS Council on 28 August, the General Council of the WTO was then presented with a final draft of the Decision on implementation of paragraph 6 of the Doha Declaration, which it adopted on 30 August 2003. ${ }^{106}$

The Decision provides for a temporary waiver of Members' obligations under Article 31(f) of the TRIPS Agreement, of the type discussed above in section IV.B of this article, until such time as that article is amended. ${ }^{107}$ Pharmaceutical products covered by the Decision include any patented product, or product manufactured through a patented process, of the pharmaceutical sector needed to address public health problems as recognised by paragraph 1 of the Doha Declaration. This explicitly includes active ingredients necessary for their manufacture and diagnostic kits needed for their use.

\footnotetext{
${ }^{103}$ The Implementation of the Doha Declaration on the TRIPS Agreement and PublicHealth, Communication from the European Communities and their Member States, IP/C/W/402, 24 June 2003.

${ }^{104}$ Paragraph 6 of the Doha Declaration on the TRIPS Agreement and Public Health, Communication from the African, Caribbean and Pacific Group of States (ACP), IP/C/W/401, 28 May 2003.

105 'Industry to Unveil Cheap Drugs Plan', Guy de Jonguières, Financial Times, 23 June 2003; 'US Rumoured to Consider Change in Tactic on TRIPS and Health’, Bridges Weekly Trade Digest, 3 July 2003, http://www.ictsd.org/weekly/03-07-03/story4.htm (visited 3 July 2003).

106 'Cheap Drugs Deal Agreed as US Lifts Veto', Frances Williams, Financial Times, 1 September 2003, 8.

${ }^{107}$ Implementation of paragraph 6 of the Doha Declaration on the TRIPS Agreement and public health, IP/C/W/405, 30 August 2003, http://www/wto/org/english/tratop_e/trips_e/implem_para6_e.htm (visited 1 September 2003).
} 
Countries eligible to import under the agreement include any least-developed WTO Member and any other Member that has notified the TRIPS Council if its intention to use the system as an importer, it being understood that a Member may notify at any time that it will use the system in whole or in a limited way, for example only in the case of a national emergency or other circumstances of extreme urgency or in cases of public non-commercial use. A number of Members (Hong Kong China, Israel, Kuwait, Macao China, Mexico, Qatar, Singapore, Chinese Taipei, Turkey and the United Arab Emirates) have stated that, if they use the system, it will only be in situations of national emergency or other circumstances of extreme urgency (this statement carrying with it the significant implication that other Members may use the system more liberally in circumstances other than in situations of national emergency or other circumstances of extreme urgency). Furthermore, as regards applicant states for European Union membership, until their accession the Czech Republic, Cyprus, Estonia, Hungary, Latvia, Lithuania, Malta, Poland, the Slovak Republic and Slovenia have all agreed that they will only use the system as importers in situations of national emergency or other circumstances of extreme urgency and, upon their accession to the EU, will opt out of using the system as importers altogether. In addition, footnote 3 to paragraph 1(b) of the Decision carries a list of developed country Members that will from the outset opt out of using the system as importers entirely. ${ }^{108}$ As regards countries allowed to sanction the manufacture and export of low-cost essential medicines under the system, the Decision makes it clear that any Member may use the system set out in the Decision to produce pharmaceutical products for, and export them to, an eligible importing country.

The Decision then goes on to set out a number of safeguards designed to ensure that cheap drugs manufactured under compulsory licensing arrangements and intended for developing countries are not diverted to developed country markets. These anti-diversion measures require that medicines made available under the scheme be a different shape and colour from those sold for profit in developed country markets, while the TRIPS Council will review periodically whether the licensing arrangements are being abused.

A separate statement by WTO General Council Chairman Carlos Pérez del Castillo, then describes Members' 'shared understanding' that the Decision will be interpreted and implemented on a 'good faith' basis in order to deal with public health problems and not for industrial or commercial policy objectives, and that issues such as preventing the medicines getting into the wrong hands are important. ${ }^{109}$ It also stresses that Members recognise that the purpose of the Decision would be defeated if products supplied under its arrangements were diverted from markets for which they are intended and that all reasonable measures should be taken to prevent such diversion, such as special packaging and/or colouring or shaping of medicines and that such measures should not have a significant impact on price. Examples of 'best practice', based on existing anti-trade diversion detection measures already taken by donor pharmaceutical companies, are appended to the statement. The statement then

\footnotetext{
${ }^{108}$ Australia, Austria, Belgium, Canada, Denmark, Finland, France, Germany, Greece, Iceland, Ireland, Italy, Japan, Luxembourg, the Netherlands, New Zealand, Norway, Portugal, Spain, Sweden, Switzerland, the United Kingdom and the United States of America.

${ }^{109}$ The General Council Chairperson's statement on implementation of paragraph 6 of the Doha Declaration on the TRIPS Agreement and public health, 30 August 2003, http://www.wto.org/english/news_e/news03_e/trips_stat_28aug03_e.htm (visited 9 September 2003).
} 
goes on the stress the role of the TRIPS Council in settling disputes arising from these arrangements expeditiously and amicably, with the TRIPS Council explicitly given a new role in reviewing notifications made under the system and all information gathered on implementation of the Decision included in the TRIPS Council annual review of the Decision.

However, concerns remain that the added costs associated with altering packaging, pill size and colour will have a detrimental effect on the availability of essential medicines in developing countries, reducing the incentives for generic drug companies, which will find it less cost-efficient to produce identifiable pills, while there are also concerns that the administrative burden associated with the procedural arrangements for notifying the WTO of its decision to use the mechanism and undergo TRIPS Council scrutiny will result in lengthy delays and prove costly for developing country governments.

There are also concerns that the Decision, which has been warmly welcomed by the Office of the United States Trade Representative, ${ }^{110}$ the European Union, ${ }^{111}$ the European Federation of Pharmaceutical Industries and Associations (EFPIA) ${ }^{112}$ and the Pharmaceutical Research and Manufacturers of America (PhRMA), ${ }^{113}$ sets out burdensome procedural arrangements. The new arrangements will require that the importing country first attempt to obtain a voluntary licence from the patent holder on reasonable commercial terms for a reasonable period. If this is not possible, the importing country must then assess its generic industry's capacity to produce the medicine locally and, if capacity is deemed insufficient, then notify the WTO with a detailed justification of its decision. The importing country must then notify a potential importer, which must in turn seek a voluntary licence and, failing that, must seek a compulsory licence from its own government on a single-country basis, with compensation payable on standards of reasonableness in the importing country. Conversely, there are still some lingering concerns for individual companies operating in the proprietary pharmaceutical industry that some high- and middle-income developing countries will not opt out from the arrangements.

The Decision is likely to have far-reaching consequences. At an institutional level, it re-defines the role of the TRIPS Council, which will now routinely scrutinise the use of compulsory licences by WTO Members by evaluating the terms of individual licences and whether or not local manufacturing capacity is insufficient. As such, the Decision opens a new chapter in the activities of the TRIPS Council. At an operational level, the Decision introduces a new level of differentiation between developing countries to an extent not previously seen in the TRIPS Agreement and

\footnotetext{
110 'Statement of US Trade Representative Robert B. Zoellick Following Agreement in WTO on Access to Medicines’, 30 August 2003, http://www.ustr.gov/releases/2003/08/2003-08-30-rbzstatement.htm (visited 11 September 2003).

111 'Access to Essential Medicines: EU Strongly Welcomes WTO Deal on Generic Medicines', 30 August 2003, http://europa.eu.int/comm/trade/issues/global/medicine/medic010903_en.htm (visited 11 September 2003).

112 'EFPIA Statement on Compulsory License for Export ("Paragraph 6" of Doha Declaration on TRIPS and Public Health’, 30 August 2003, htto:/www.efpia.org/3_press/20030830.htm (visited 11 September 2003).

113 'Statement from Shannon Herzfeld, PhRMA's Senior Vice President, International Affairs in relation to successful conclusion of the negotiations on TRIPS and Public Health', 30 August 2003, http://www.phrma.org/mediaroom/press/releases/30.08.2003.841.cfm (visited 11 September 2003).
} 
also carries with it a number of uncertainties and additional obstacles for those WTO Members seeking to avail themselves of the new procedures. However, the Decision does mark a step back from the more restrictive interpretation of a paragraph 6 solution advocated by the EU and US in earlier negotiations. The arrangements outlined in the final text of the Decision do not limit the scope of diseases, nor as a general rule require a national emergency such as an epidemic to be identified before compulsory licences can be issued since public health problems can now routinely be dealt with under the agreed arrangements. Yet, aside from the institutional and operational consequences of the Decision, one of its most far-reaching consequences may well be the legacy that negotiations will leave in terms of providing the stimulus for policy alternatives to a Doha-based solution.

\section{Policy alternatives to a Doha-based solution}

\section{A. Pharmaceutical companies as donors of essential medicines}

A significant alternative to a Doha-based solution is emerging due to the fact that pharmaceutical companies are facing investor pressure to exhibit good practice. On 24 March 2003, for instance, ISIS Asset Management and the UK Universities Superannuation Scheme (USS) published an investor statement urging pharmaceutical companies and governments to improve access to medicines in developing countries. The investor statement was accompanied by a framework of good practice by which to assess pharmaceutical companies' commitment to improving public health in the developing world by observing sensitivity to local circumstances when enforcing patents or granting licences. It also advocated using influence with governments to encourage measures to address public health crises, such as through government contributions to the Global Health Fund (see sub-section D, below). ${ }^{114}$

Some pharmaceutical companies have responded with donations of medicines to developing countries free of charge. ${ }^{115}$ However, the slow take up of such offers by governments in sub-Saharan Africa is puzzling. Since 2000 only two African countries (Uganda and Botswana) have accepted an offer by German pharmaceutical company Boehringer Ingelheim to provide free donations of nevirapine, an antiretroviral drug sold under the brand name Viramune and designed to prevent pregnant women suffering from the HIV/AIDS virus infecting their unborn babies. ${ }^{116}$ This low take up may be due to continuing scepticism about the efficacy of nevirapine, particularly in South Africa, but may also indicate that complicated bureaucracy on the part of the donor company, an absence of political commitment by developing country governments, shortcomings in local healthcare systems and problems with distribution channels may all create significant barriers to access for essential medicines. ${ }^{117}$

\footnotetext{
114 The Guardian ‘Investors Pressure Drug Firms on Pricing’, 25 March 2003, 12.

${ }^{115}$ For examples see Rozek, above n. 4, at 912.

116 ‘Only Two African States Take Up Aids Offer', Geoff Dyer, Financial Times, 14 July 2003, 8.

${ }^{117}$ See also Bourgeois and Burns, above n. 3, at 839.
} 


\section{B. Differential pricing and the prevention of trade diversion}

\section{Parallel importation}

One solution that would stop short of creating a developing country dependence on corporate donations of free medicines, while acknowledging the inability of patients in developing countries to pay developed world prices for patented essential medicines, would be for pharmaceutical companies to simply provide cheap drugs to alleviate public health crisis in developing countries. Drug companies are, for instance, offering price reductions of up to 75 per cent for anti-retroviral drugs to combat the virus in developing countries. ${ }^{118}$ But problems arise because the doctrine of international exhaustion of rights, embodied in the TRIPS Agreement and confirmed in the Doha Declaration, can lead to parallel importation. Parallel importation occurs when products made and marketed by the patent owner in one country are imported into another country without the approval of the patent owner, normally in order to take advantage of differential pricing between the two countries, whereby different prices are available for the same product in different markets. ${ }^{119}$ This becomes problematic for initiatives designed to promote access to affordable medicines required to address public health crises in developing countries where there is a substantial risk that low-cost, differentially priced, medicines made available in developing countries will be diverted back into more lucrative developed country markets where they can be sold for higher prices.

Under rules of international exhaustion, set out in Article 6 of the TRIPS Agreement, a patentee's rights are exhausted as soon as the patented product is put on the market either by the patentee or with his consent. The result is that a patent cannot prevent the marketing or importation of the goods by others once it has been placed on the market with the consent of the patentee. ${ }^{120}$ This rule prevails since Article 6 of the TRIPS Agreement merely provides that 'nothing in this Agreement shall be used to address the issue of the exhaustion of intellectual property rights'. This principle has been is confirmed by paragraph 5(d) of the Doha Declaration, which states that 'the effect of the provisions of the TRIPS Agreement that are relevant to the exhaustion of intellectual property rights is to leave each Member free to establish its own regime for such exhaustion without challenge...' ${ }^{121}$ The effect of international exhaustion, as established by Article 6 of the TRIPs Agreement, may well be, therefore, to dissuade patent holders from offering their products at low cost in developing countries.

There is also an associated risk of transparency for global pharmaceutical companies involved with differential pricing initiatives in that supplying low-cost drugs to developing countries could lead customers in the developed world to notice that they were paying, for example, $\$ 100$ per kilo as opposed to the developing

\footnotetext{
${ }^{118}$ Bale, above n. 93, at 1; Rozek and Rainey, above n. 3, at 477; Subramanian, above n. 19, at 330; World Health Organisation, above n. 2, at 4.

${ }^{119}$ See also Bartelt, above n. 10, at 304.

${ }^{120}$ See also Marco M. Slotboom, 'The Exhaustion of Intellectual Property Rights: Different Approaches in EC and WTO Law’, 6 (3) Journal of World Intellectual Property 421 (2003), at 423.

${ }^{121}$ For Slotboom (ibid., at 433), while Article 6 of the TRIPs Agreement was an 'agreement to disagree', Paragraph 5(d) of the Doha Declaration reflects something more of a 'positive "agreement" that goes beyond Article 6', in the form of 'another expression that WTO law in general leaves the policy of exhaustion to the discretion of WTO Members'.
} 
country price of $\$ 10$ per kilo for identical medicines, with resultant public pressure to lower prices in developed world markets. Furthermore, uncontrolled re-exports of low-cost medicines from developing countries back into developed world may also lead to a downward pressure on prices in the latter markets. ${ }^{122}$ Although Rozek argues that the existence of differential prices for pharmaceutical products is not necessarily a cause for concern and are an efficient means for pharmaceutical companies to recover research and development costs, ${ }^{123}$ it is more generally acknowledged that pharmaceutical companies would 'rather avoid large differentials in prices across markets because of the pressure from taxpayers and consumers in their own markets who see the price differential as being unfair to them'. ${ }^{124}$

\section{The EU Regulation to prevent diversion of trade in low-cost essential medicines}

The fact that Article 6 of the TRIPS Agreement leaves each Member free to establish its own regime of exhaustion of rights creates a structural weakness, which acts as a disincentive for the provision of donated or low-cost patented medicines to developing countries. The European Union operates its own regional exhaustion of rights doctrine, so imports of cheaper patented medicines from outside the EU are prohibited. This has made it possible for the EU to put in place safeguards to deter diversion of trade in essential medicines that have been made available at low cost or, donated free of charge, by patent holding proprietary pharmaceutical companies. As such, the EU arrangements differ from the system agreed by the WTO in its Decision on a paragraph 6 solution of 30 August 2003, the latter being designed to deter trade diversion in circumstances where generic drug producers manufacture and export to developing countries low-cost medicines under compulsory licensing conditions. As the EU and WTO systems take effect, however, it will be interesting to compare the effectiveness of each set of arrangements as they operate alongside each other, at least as far as WTO Members from EU countries are concerned.

The details of the EU arrangements were agreed on 23 May 2003, when the Council of the European Union took steps to stop low-cost medicines intended for developing countries from being re-imported into Europe by adopting a Council Regulation, under which exporting companies are invited to apply to the European Commission for permission to put their medicines to combat HIV/AIDS, malaria, tuberculosis and related opportunistic diseases onto a 'tiered' price list, selling them to developing countries at a minimum of a quarter of the average factory price in OECD or at the cost of production plus a 15 per cent margin. ${ }^{125}$ The Regulation prohibits the re-importation of these drugs into the EU from 76 least developed and developing countries listed in Annex II. The products on the list then carry a logo the winged staff of Aesculapius with a coiled serpent in the centre of a circle formed

\footnotetext{
122 See also Reichman, above n. 12, at 15.

${ }^{123}$ Rozek, above n. 4, at 893; Rozek and Rainey, above n. 4, at 475.

${ }^{124}$ Subramanian, above n. 19, at 325.

${ }^{125}$ Council Regulation (EC) No. 953/2003 of 26 May 2003 to avoid trade diversion into the European Union of certain key medicines, OJL 135/5, 3 June 2003. See also 'EU Bars Reimport of Drugs Headed for Poor Countries’, Bloomberg News, 27 May 2003, http://www.iht.com/articles/97561.html (visited 27 May 2003); 'EU Acts to Speed Up Flow of Cheap AIDS Drugs’, Tobias Buck, Financial Times, 26 May 2003, http://news.ft.com/business (visited 27 May 2003); 'Access to Medicines: EU Clears Plan to Ensure Delivery of Cheap Medicines to Developing Countries', European Union Press Release, 26 May 2003, http://europa.eu.int/comm/trade/csc/med.htm (visited 27 May 2003).
} 
by 12 stars - as depicted in Annex V of the Regulation - allowing easy identification by customs authorities examining imported goods at EU borders. ${ }^{126}$

In fact, it was the EU that proposed similar safeguards be put in place at WTO level with generic producers and importers using compulsory licensing provisions taking necessary measures to prevent trade diversion, including making medicines produced under the exemption clearly distinguishable through labelling, marking and packaging. ${ }^{127}$ Potentially, this pragmatic approach to prevention trade diversion of low-cost medicines can have major advantages for recipients of low-cost medicines in developing countries. If the EU arrangements work effectively, it may be time to look again at the issue of international exhaustion and explicitly to re-open the debate as to whether Article 6 of the TRIPS Agreement could be revised to provide an effective mechanism to prevent the diversion of low-cost or donor drugs supplied by proprietary drug companies, and intended for low-income developing countries, back into developed country markets.

\section{Preventing the diversion of generic drugs produced under compulsory licensing}

Although the matter is not clearly settled, it is highly unlikely that parallel importation under the doctrine of exhaustion applies in the case of the separate problem of pharmaceutical products produced under compulsory licensing conditions. ${ }^{128}$ But, even though the situation regarding generic drugs produced under a compulsory licence would be likely to differ from the situation with low-cost or donor drugs produced by proprietary pharmaceutical companies, since the patent holder would not have given consent to the marketing of a generic drug, there has traditionally been an expectation that the right holder would be able to block importation of generics manufactured under compulsory licences. ${ }^{129}$ However, in reality, the situation may well be that, particularly where a product is manufactured under a compulsory licence for export, diversion of the product away from the developing country market that it was intended for and into developed countries instead, where higher prices can be charged, may undermine the market for the patented version of the product. The EU initiative may therefore have usefulness in terms of preventing the export of generic medicines produced under compulsory licences into developed country markets that goes well beyond the original objective of the Regulation if a similar uniform identification and registration procedure could be set up at WTO level, in effect a tightening of the arrangements designed to prevent trade diversion set out in the WTO Decision of 30 August which at present leaves the detail of how the system should operate to individual importing Member countries.

\footnotetext{
${ }^{126}$ Aesculapius was the Greek God of Medicine. Homer called Aesculapius the 'blameless physician'. According to legend his father, Apollo, gave Aesculapius healing powers that were so powerful that he started to raise people from the dead. Unhappy about losing the privilege of immortality, Zeus killed Aesculapius with a thunder bolt.

${ }^{127}$ Communication from the European Communities and their Member States, above n. 74, para 5.

${ }^{128}$ Reichman, above n. 12, at 16.

${ }^{129}$ Bartelt, above n. 10, at 305. See also Reichman, above n. 12, at 16, for a discussion of differing views on whether importing states have the right to treat products initially sold under a compulsory licence in the exporting state as parallel imports for the purposes of Article 31 and Paragraph 5(d) of the Doha Declaration.
} 


\section{Public private partnerships}

An alternative to developing country dependence on donations or access to low-cost essential medicines from global pharmaceutical companies is emerging in the form of public-private partnerships (PPPs). As a model for initiating research into developing country diseases, PPPs reduce the need to tackle the reform of intellectual property systems as a prerequisite to improving public health. Under the PPP model, companies provide technology, as well as development and distribution expertise, while public sector partners fund development costs and help to ensure that medicines and vaccines get to people that need them. This, argue the advocates of PPPs, has the double benefit of encouraging $R \& D$ and accelerating the product's uptake in the developing world. ${ }^{130}$ Following the recommendation of the CIPR report that public funding for research on health problems in developing countries should be increased, ${ }^{131}$ the UK Government's response was that it recognised that a range of public policies were required to help alleviate health problems in developing countries and that public funding was an important element of this overall strategy. ${ }^{132}$ The UK Government has already demonstrated a willingness to provide public funding to help create PPPs, a recent example being the announcement by GlaxoSmithKlein (GSK) that it plans to launch the drug Lapdap (chlorpoguanil/dapsone) for the treatment of malaria. The Lapdap initiative, the result of a partnership initiative between GSK, the WHO, the University of Liverpool, the London School of Hygiene and Tropical Medicine, received funding of $£ 2.5$ million from the UK Government’s Department for International Development (DFID).

\section{The Global Fund}

What the efforts of corporate donors and public-private partnerships do, in many respects, is to illustrate that a Doha-based solution is only part of a range of policy approaches designed to achieve the overall goal of improving standards of healthcare in developing countries through a mix of mechanisms involving corporate donors, public money and public-private partnerships. With financing of essential medicines programmes a real problem in developing countries ${ }^{133}$ there is a wider need for the Doha negotiations to be accompanied by global commitment to financing health improvements in developing countries. ${ }^{134}$ One practical embodiment of this commitment is the Global Fund to Fight AIDS, Tuberculosis and Malaria, ${ }^{135}$ set up in 2001 to finance programmes for epidemics in developing countries. In his State of the Union address on 28 January 2003, President George W. Bush committed himself to asking the United States Congress to authorise up to $\$ 1$ bn per year for five years for the Global Fund but, even with France announcing its intention to triple donations to

\footnotetext{
${ }^{130}$ See, for instance, the presentation given on 12 February 2003 at the Overseas Development Institute, London, by Chris Strutt, Vice-President, External Relations, Worldwide and International, GlaxoSmithKlein: http://www.odi.org.uk/speeches/IPR_2003/gsk_ppp_files/frame.html (visited 25 April 2003).

${ }^{131}$ Commission on Intellectual Property Rights, above n. 5, at 34.

132 The UK Government Response to The Report of the Commission on Intellectual Property Rights, above n. 5 , at 5 .

133 Thomas Cottier, ‘TRIPs, the Doha Declaration and Public Health’, 6 (2) Journal of World Intellectual Property, 385 (2003), at 385; Noehrenberg, above n. 3, at 381.

${ }^{134}$ See also Bourgeois and Burns, above n. 3, at 840; Ismail, above n. 4, at 395.

135 The Global Fund to Fight AIDS, tuberculosis and malaria', http://www.globalfundatm.org/ (visited 27 April 2003).
} 
the Global Fund to $\$ 150 \mathrm{~m}$ per year and UK committed to donating $\$ 45 \mathrm{~m}$ per annum, co-ordinated action from the European Union has so far been absent and the Global Fund is already suffering from a shortfall. The G8 countries have been criticised for not increasing their financial contributions, despite pledging to strengthen efforts to fight HIV/AIDS, tuberculosis and malaria in its action plan on health on 2 June 2003. ${ }^{136}$ Around $\$ 450 \mathrm{~m}$ is needed to finance the proposals from developing countries that the Fund intends to approve in October 2003 and a further \$3bn would be needed to meet likely commitments before the end of 2004. ${ }^{137}$ A further commitment to the Global Fund, particularly by the EU, is essential if its objectives are to be met.

\section{E. The World Health Assembly}

In a move related to the Doha negotiations, at the $56^{\text {th }}$ World Health Assembly in May 2003, proposals from Brazil, on behalf of developing countries, ${ }^{138}$ and from the United States, ${ }^{139}$ resulted in the adoption of a Resolution on Intellectual Property Rights, Innovation and Public Health. ${ }^{140}$ The Resolution provides for the setting up a body which appears akin to the UK Commission on Intellectual Property Rights (CIPR), and instructs the WHO to establish the terms of reference for an appropriate time-limited expert body to collect data and produce an analysis of intellectual property rights, innovation and public health, including the question of appropriate funding and incentive mechanisms for the creation of new medicines and other products against diseases that disproportionately affect developing countries. The Resolution provides for submitting a progress report to the $57^{\text {th }}$ World Health Assembly and a final report with concrete proposals to the Executive Board of the WHO at its $115^{\text {th }}$ session in January 2005. Although this involvement for the WHO in the intellectual property and public health debate remains at the preparatory stages, this initiative nevertheless marks a potentially significant shift in the activities of the World Health Organisation in this area. ${ }^{141}$

\section{Conclusions: risks and opportunities for the future}

It is somewhat ironic that, in the final instance, it was US refusal to the accept the Chairman's compromise text on 20 December 2002 that led the deadline set by paragraph 6 of the Doha Declaration to be missed. In many respects it was developing countries, not the US, which had most to lose by demonstrating a willingness to agree to the Chairman's draft. But the change in approach on the part of the United States in

\footnotetext{
136 'G8 Pledges Greater Efforts to Fight AIDS/HIV', http://usinfo.state.gov/cgibin/washfile/display.pl?p=/products/washfile/latest\&f=03060203.glt\&t=/products/washfile/nesitem.sht ml (visited 2 June 2003).

137 'Bush Aids plan “would allow purchase of cheap generic drugs”', Geoff Dyer, Financial Times, 16 July 2003, page 9; 'Aids activists barrack Chirac after conference leaves fund facing shortfall’, Geoff Dyer, Financial Times, 17 July 2003, 7.

${ }^{138} 56^{\text {th }}$ World Health Assembly agenda item 14.9, A56/A/Conf.Paper No. 2, 21 May 2003, Intellectual Property Rights, Innovation and Public Health, draft resolution proposed by the delegation of Brazil. 139 'US Move on Drug Patents Under Attack', Frances Williams, Financial Times, 23 May 2003, http://news.ft.com/servlet/ContentServer?pagename=3DFT.com/StoryFT/FullStory=y\&c=3DstoryFT\& cid=3D1051390270549 (visited 23 May 2003)

${ }^{140}$ World Health Assembly Fourth Report of Committee A, containing final text of Resolution on Intellectual Property Rights, Innovation and Public Health, http://www.who.int/gb/EB_WHA/PDF/WHA56?ea5666.pdf (viewed 28 May 2003).

141 'WHO to Gain Advisory Role on Pharmaceutical Patents', Frances Williams, Financial Times, 28 May 2003, 13.
} 
August 2003 ultimately meant that agreement, in the form of the 30 August Decision, could be put in place, albeit with additional procedural safeguards to those suggested the previous December. NGOs, generic drug companies ${ }^{142}$ and international institutions played a significant role in seeking to re-define and re-align the rules of international intellectual property law, at one point during the negotiations Eric Noehrenberg of the International Federation of Pharmaceutical Manufacturers Association even complaining that countries such as Argentina, Brazil, Hungary and India with strong generic drug industries had 'hijacked' and 'subverted' the paragraph 6 process by promoting the availability of off-patent medicines in all developing countries, in doing so preventing progress on reaching the intended beneficiaries in countries with low incomes or insufficient manufacturing capacities. ${ }^{143}$ But ultimately the outcome, characterised by the dominance of the US and the EU as key institutional actors, coupled with the reluctance of developing country governments to ultimately oppose the US approach in the face of negotiating fatigue and the threat of bilateral trade sanctions, is remarkably familiar and repeats the patterns of earlier negotiations. ${ }^{144}$

But despite the WTO Decision of 30 August 2003, the stakes remain high. One potential adverse impact of accepting a system that may lead to more frequent recourse to compulsory licensing may, of course, be a continuation of the dearth of research into diseases of particular importance to developing countries, such as malaria and drug-resistant tuberculosis. The presumption that greater patent protection in developing countries under the terms of the TRIPS Agreement would result in increased levels of research into tropical diseases, with the prospect of significant financial rewards for pharmaceutical companies holding key patents would, argues Sykes, be likely to be undermined by a more liberal interpretation of TRIPS provisions on compulsory licensing and parallel importation. ${ }^{145}$ There remains a risk that a pharmaceutical company considering investing in research and development into diseases that particularly affect developing countries might consider this unviable in commercial terms if compulsory licences are subsequently awarded and importation allowed into the affected area with only reduced compensatory payments awarded to the patent holder. ${ }^{146}$

There is also the risk that the US remains prepared to take tough unilateral action if developing countries try to use cheap generic drugs. This is a form of the 'TRIPS-plus' bilateral action outlined by Drahos, ${ }^{147}$ while a further manifestation of TRIPS-plus might well occur through the introduction of bilateral trade agreements, such as the draft Free Trade Area for the Americas (FTAA), ${ }^{148}$ namely a ratcheting up

\footnotetext{
${ }^{142}$ For example, on 2 December 2002, Jerome Smith, Chief Executive Officer of Medpro Pharmaceutica, South Africa, wrote to Members of the TRIPS Council on behalf of African generic drug manufacturers, commenting on negotiation of paragraph 6 of the Doha Declaration and urging negotiators to adopt a solution that encourages the further development of domestic value added companies in Africa, and which enables competition for the supply of pharmaceuticals, vaccines and other health care inventions. The letter supported the EP Amendment 196 solution as the correct approach for Africa.

${ }^{143}$ Noehrenberg, above n. 3, at 380.

${ }^{144}$ Matthews, above n. 49,

${ }^{145}$ Sykes, above n. 43 , at 4 .

${ }^{146}$ Sykes, above n. 43, at 22.

${ }^{147}$ Peter Drahos, 'Bilateralism in Intellectual Property', Oxfam Policy Paper (2001).

148 http://www.ftaa-alca.org/alca_e.asp (visited 26 April 2003).
} 
of standards to limit compulsory licensing through trade agreements outside the remit of the WTO. Developing countries may well be prepared to sign such agreements in order to avoid losing access to developed country markets. ${ }^{149}$

But, as well as risks, the future also holds out opportunities, particularly for least-developed countries. From 2005 onwards, when patents for pharmaceuticals will be extended to developing countries, least-developed nations will remain the only group of WTO Members that will retain transitional arrangements with respect to the obligation to provide patent protection for pharmaceuticals, until 2016. This extension for least-developed countries exists as a result of Article 66 of the TRIPS Agreement and the associated extension of the deadline in the Doha Declaration on the TRIPS Agreement and Public Health, subsequently adopted as a Decision of the TRIPS Council to this effect on 1 July $2002 .{ }^{150}$ As a result, there is now anecdotal evidence that several leading Indian generic drug manufacturers are considering moving their operations to Bangladesh to take advantage of the least-developed country status (and associated longer transitional periods) in that country. ${ }^{151}$

Yet despite the potential short-term benefits for some least-developed countries, the reality is that the debate about the Doha Declaration and compulsory licensing is part of a much wider structural problem in development policy. ${ }^{152}$ Improving health care systems and public health awareness via education programmes, plus new research into treatments for diseases prevalent in developing countries will all be crucial. In many respects, one of the key achievements of the negotiations that have followed the Doha Declaration is probably on a political level, ${ }^{153}$ refocusing attention on the severity of the public health problems facing developing countries, with the resultant investor pressure on pharmaceutical companies to enter into donor initiatives and public private partnerships. Overall, solutions are likely to emerge as much from pragmatic initiatives and incremental steps as from the legal undertakings on an acceptable form of words to resolve the process initiated by paragraph 6 of the Doha Declaration, agreed in the WTO Decision of 30 August 2003. The actions of corporate donors and public-private partnerships are part of this solution, as are increased contributions of public money to the Global Fund. Alongside these initiatives, it may well be that regulatory activity such as the European Union Regulation, taking advantage of the EU doctrine of regional exhaustion by linking low-cost and donor medicines to measures taken by customs EU officials to prevent re-importation of these drugs into the EU from a predetermined list of 76 least-developed and developing countries, is the type of measure that has the potential to address public health crises in the developing world by preventing the diversion of trade medicines intended for developing countries. Perhaps such initiatives can even achieve as much as the painful and protracted negotiations between WTO Members on how best to ensure access to essential medicines in developing countries by means of a solution to the paragraph 6 problem

\footnotetext{
${ }^{149}$ See also Drahos, above n. 39, at 783.

${ }^{150}$ Decision of the Council for Trade-Related Aspects of Intellectual Property Rights, Extension of the Transition Period Under Article 66.1 of the TRIPS Agreement for Least-Developed Country Members for Certain Obligations with Respect to Pharmaceutical Products, 1 July 2002, IP/C/25.

${ }^{151}$ See also Haag, above n. 58, at 981; Noehrenberg, above n. 3, at 382.

152 See also Reichman, above n. 12, at 27.

${ }^{153}$ See also Reichman above n. 12, at 17.
} 
of the Doha Declaration that have taken up so much time and energy over the past two years. 